\title{
A comparison of on-curricular and off-curricular activities in enterprise education for postgraduate students
}

\author{
Kassandra A. Papadopoulou, Robert A. Phillips
}

Alliance Manchester Business School, University of Manchester, United Kingdom.

\begin{abstract}
A comparison of the effectiveness of two educational activities are carried out; a standard on-curricular postgraduate unit and an off-curricular school activity. The taught area for both is the theme of enterprise and entrepreneurship. They share similar intended learning outcomes, equipping participants with the same skills, knowledge and tools to set up their own business start-up. Another similarity is the number of contact hours with the students, however the main difference is the span these two activities take place; over a full semester or over a week. A survey was designed to be used in post teaching sessions to evaluate the effectiveness and impact the activities had on the students in the area of enterprise and entrepreneurship. The results indicated that both activities had an impact on start-up intention and activity however, the cost of the enterprise school per head and the fact that the on-curricular activities provide a recognized qualification in case the business fails means that short intensive off-curricular activities are better suited for researchers with limited time and who are still open minded about career choices. Both activities serve their own purpose and value as they provide the desired interventions for supporting positive attitudes towards enterprise and entrepreneurship.
\end{abstract}

Keywords: Business start-up; Education; Entrepreneurship; Enterprise; Offcurricular; On-curricular. 


\section{Introduction}

Enterprise and entrepreneurship education activities, both on- and off- curricular, for postgraduates are increasingly common throughout The University of Manchester (UoM) (Phillips, 2018). This includes both the Master of Enterprise (M.Ent.) unit Shaping Ideas for the Market (SIM) and the Enterprise School (ES) delivered by the Manchester Enterprise Centre (MEC). On-curricular activities the authors consider to be accredited units, optional or compulsory where entrepreneurship or enterprise education is a key component and entrepreneurial learning outcomes are assessed, e.g. the SIM unit. Off-curricular are activities which are voluntary and not credit bearing, e.g. the ES, Business Plan Competitions. The M.Ent. degree enables students to develop their entrepreneurial skills and start their own business or work for a company where enterprise and innovation are valued. SIM is one of the two core 15 credit units, two elective units are studied and a research project with a potential commercial application is carried out. It focuses on identification of opportunities and the development of business models. It includes various methods for obtaining market intelligence, analysis, identification, evaluate and refine valuable opportunities (UoM, 2019). The internal MEC records show that since 2001 more than 60 companies have been set up by the participants attending the SIM unit (unpublished data). The ES is an off-site activity (Phillips, 2017 \& Phillips, 2010) where self-selecting postgraduates from any discipline attend for an intensive four days of entrepreneurship training, working in groups on an opportunity they identify in the local area to create economic or social value. It involves an introductory session followed by students putting into practice the skills learned and students complete a personal journal as a record of their learning (Phillips, 2008). Data suggests about $10 \%$ of students have started a business within a year of returning from the ES (Phillips, 2017).

\subsection{Aim and Objectives}

The two activities have the same aim in providing entrepreneurial education and providing skill sets for students setting up their businesses. They run in the same academic year, both are aimed at postgraduate students, and their main characteristics are presented in Table 1. The aim of this paper is to study the effectiveness of two types of academic activities in the area of enterprise that have on student attitude to setting up their business and on the skills that they have obtained attending this. The two types of deliveries although have the same contact hours, they have a different time span, the SIM unit is across 12 weeks (one semester) and the ES is across four days. The objectives are to: (i) provide a short description and analysis of what those activities offer, (ii) identify what is the perspective of the students attending them, and (iii) what the students gain from each activity. 


\section{Literature Review}

The taught curriculum and off-curricular activities create the entire student experience (Fry et al., 2015). The curriculum allows universities to differentiate themselves by expressing their individuality and focus on issues e.g. internationalisation, employability all of which are part of UoM agenda. While the university curriculum and its theoretical dimensions are well known in the academic world, the need to modify from traditional curriculum models to a more adaptive self-learning such as off-curricular has been suggested for a long time. Crompton (1987) mentions that the curriculum should be based on learning and not on knowledge, students should not be restricted by a curriculum that concentrates on the academic above the practical aspect. "Learning by Doing" is accepted as being a good method for encouraging entrepreneurial mindsets and is used on UoM enterprise courses (Sanchez-Romaguera \& Phillips, 2018). The methods implemented by MEC for the two activities are in line with the Quality Assurance Agency and best practice, where the aim of the enterprise and entrepreneurship education is to provide interventions for supporting behaviours, and qualities that would provide students with the confidence to set up their own businesses and have a significant impact in successful careers that would add economic, social and cultural value to the UK (QAA, 2018). In the UK, a strong policy context exists for the development of enterprise and entrepreneurial education within Higher Education that is closely associated with employability enhancement (Artess et al., 2017). Enterprise education that enhances employability requires a different approach to traditional learning and teaching pedagogies, which the two activities here strive to achieve. Off-curricular initiatives arising from the delivery of enterprise and entrepreneurialism include those that have the capacity to change institutional culture or practice (Artess et al., 2017). Universities pursue to increase graduate employability business schools state the importance on 'developing the next generation of entrepreneurs' Bell (2016) which is also the motto of the M.Ent. There are no clear teaching methods on how to best encourage both entrepreneurialism and employability in students and this area is still a developing field. The literature on the effectiveness of entrepreneurship education is not conclusive, theories argue that entrepreneurship skills can be taught but entrepreneurship is partly an 'art' and cannot be taught. On the other hand, recent studies stated that entrepreneurial programmes have impacted on students' entrepreneurialism in an effective way (Bell, 2016). A metaanalysis study by Martin et al. (2013) found overall there was evidence to support that entrepreneurship training was effective. Effectiveness has been measured using a variety of methods including self-efficacy and start-up rates, in some cases followed over a considerable length of time (Matlay \& Carey, 2007). With respect to extra-curricular activities, according to Kneale (2009), these are created to attract students who have an interest in enterprise but do not want to enrol to a whole module. The on-curricular lectures were well attended however attendance on not-for-credit or off-curricular activities 
attendance was less consistent. It was found that the extra-circular activities were valuable 'signposts', but they could not offer the consistency of learning gained through the oncurricular modules. Students are unlikely to pursue a not-for-credit enterprise agenda unless they are very motivated. The extra-curricular activities, although undoubtedly enhancing the student experience, they are not financially viable on their own (Kneale, 2009).

\section{Methodology}

The methodology includes primary data collection across the two activities. A short survey, was carried out just after the completion of both activities, to identify if the enterprise activities had any effect in the participants linked to that aim and objectives. Table 1 shows the characteristics of the two activities.

Table 1. Characteristics of the two enterprise education activities.

\begin{tabular}{ccc}
\hline Type of Activity & SIM (hrs) & ES (hrs) \\
\hline Total in-class contact hours & 33 & 21 \\
Taught material from lecturers & 20.5 & 6 \\
Presentations/Mentoring from guest entrepreneurs/speakers & 7.5 & 4 \\
Workshop/tutorial/group working & 2 & 6 \\
Social activities & 0 & 20 (optional) \\
Coursework (out of class hours activity) & 117 & 0 \\
\hline
\end{tabular}

\section{Results and Discussion}

The results of the surveys for the two enterprise education activities are shown in Tables 28.

Table 2. Question 1 Are you more likely to start a business having participated in ES or SIM?

\begin{tabular}{ccccc}
\hline & $\begin{array}{c}\text { SIM no of } \\
\text { responses }\end{array}$ & $\begin{array}{c}\text { SIM response } \\
\%\end{array}$ & $\begin{array}{c}\text { ES no of } \\
\text { responses }\end{array}$ & $\begin{array}{c}\text { ES response } \\
\%\end{array}$ \\
\hline Yes & 6 & 86 & 29 & 64.4 \\
No & 0 & 0 & 0 & 0 \\
The same & 1 & 14 & 16 & 35.6 \\
\hline
\end{tabular}


Most students say they are more likely to start a business after attending this unit (there are participants in the course that already have started their own businesses). None seemed put off by the training as has sometimes been found elsewhere.

Table 3. Question 2 What are your career aspirations?

\begin{tabular}{ccccc}
\hline & $\begin{array}{c}\text { SIM no of } \\
\text { responses }\end{array}$ & $\begin{array}{c}\text { SIM response } \\
\text { \% }\end{array}$ & $\begin{array}{c}\text { ES no of } \\
\text { responses }\end{array}$ & $\begin{array}{c}\text { ES response } \\
\%\end{array}$ \\
\hline Work in Industry & 1 & 14 & 16 & 36 \\
Technology Transfer & 0 & 0 & 11 & 24.3 \\
Academic position & 0 & 0 & 8 & 18 \\
Start Own Business & 6 & 86 & 6 & 13 \\
Consultancy & 0 & 0 & 3 & 6.7 \\
Not for profit & 0 & 0 & 1 & 2 \\
\hline
\end{tabular}

All students but one are more likely to start their own business after attending SIM (there are students that work already part time in industry). For ES, the participants had a broader range of career aspirations despite the self-selecting nature of the course. 
Table 4. Question 3 What would be the reason for you starting a business? (two options)

\begin{tabular}{ccccc}
\hline & $\begin{array}{c}\text { SIM no of } \\
\text { responses }\end{array}$ & SIM response \% & $\begin{array}{c}\text { ES no of } \\
\text { responses }\end{array}$ & ES response \% \\
\hline $\begin{array}{c}\text { To improve society } \\
\text { To be better off } \\
\text { financially }\end{array}$ & 0 & 57 & 22 & 97.8 \\
$\begin{array}{c}\text { For the excitement } \\
\text { To be own boss }\end{array}$ & 2 & 29 & 16 & 88.89 \\
$\begin{array}{c}\text { To create own job } \\
\text { Raise funds for } \\
\text { research }\end{array}$ & 4 & 57 & 14 & 71.1 \\
Status & 0 & 29 & 4 & 62.2 \\
Create a spin-out & 0 & 0 & 2 & 17.78 \\
company & 0 & 0 & 1 & 4.89 \\
Other & 2 & 0 & 1 & 4.4 \\
\hline
\end{tabular}

The main motives for the SIM students starting their own business is to be better off financially and to be their own bosses. However, for ES, improving society was rated highest which links with the anecdotal view that many of the students attending had an interest in social entrepreneurship regardless of their background. 
Table 5. Question 4 What factors would encourage you to start a business? (two options)

\begin{tabular}{ccccc}
\hline & $\begin{array}{c}\text { SIM no of } \\
\text { responses }\end{array}$ & $\begin{array}{c}\text { SIM response } \\
\text { \% }\end{array}$ & $\begin{array}{c}\text { ES no of } \\
\text { responses }\end{array}$ & $\begin{array}{c}\text { ES response } \\
\%\end{array}$ \\
\hline $\begin{array}{c}\text { If they could see how it } \\
\text { would benefit society } \\
\text { More training }\end{array}$ & 3 & 43 & 22 & 97.8 \\
$\begin{array}{c}\text { If they spotted an } \\
\text { opportunity }\end{array}$ & 4 & 0 & 19 & 84.4 \\
$\begin{array}{c}\text { If they saw more } \\
\text { examples from their own } \\
\text { area }\end{array}$ & 0 & 57 & 18 & 80 \\
$\begin{array}{c}\text { If it increased chance of } \\
\text { getting research grants }\end{array}$ & 1 & 0 & 11 & 48.89 \\
If they had funding & 3 & 25 & 5 & 22.22 \\
Other & 2 & 43 & 1 & 4.4 \\
\hline
\end{tabular}

For ES, they seemed to be encouraged by seeing how their idea could benefit society, whilst those on SIM suggested spotting an opportunity might be the most encouraging factor. Those on SIM felt that no more training was required, although this was rated highly by ES participants.

Table 6. Question 5 What do you feel are the barriers to starting a business? (two options)*

\begin{tabular}{ccccc}
\hline $\begin{array}{c}\text { *selected answers } \\
\text { presented }\end{array}$ & $\begin{array}{c}\text { SIM no of } \\
\text { responses }\end{array}$ & $\begin{array}{c}\text { SIM response } \\
\text { \% }\end{array}$ & ES no of responses & $\begin{array}{c}\text { ES response } \\
\%\end{array}$ \\
\hline Lack of Finance & 5 & 71 & 19 & 84.4 \\
Lack of Time & 2 & 29 & 13 & 57.8 \\
Risky & 3 & 43 & 6 & 71.1 \\
\hline
\end{tabular}

This question had the most diverse answers. The most popular answer was lack of finance, it is risky as most popular. Other answers were lack of time, support and little commercial application. 
Table 7. Question 6 When would you ideally start a business?

\begin{tabular}{ccccc}
\hline & $\begin{array}{c}\text { SIM no of } \\
\text { responses }\end{array}$ & $\begin{array}{c}\text { SIM response } \\
\text { \% }\end{array}$ & $\begin{array}{c}\text { ES no of } \\
\text { responses }\end{array}$ & $\begin{array}{c}\text { ES response } \\
\%\end{array}$ \\
\hline $\begin{array}{c}\text { Start a business after gaining } \\
\text { industry experience }\end{array}$ & 2 & 29 & 21 & 46.7 \\
$\begin{array}{c}\text { Start a business as soon as } \\
\text { you leave university }\end{array}$ & 4 & 57 & 11 & 24.4 \\
$\begin{array}{c}\text { Create an academic spin out } \\
\text { company while in an } \\
\text { academic position }\end{array}$ & 0 & 0 & 7 & 15.6 \\
$\begin{array}{c}\text { Be an intrapreneur in a } \\
\text { larger organisation }\end{array}$ & 1 & 14 & 6 & 13.3 \\
\hline
\end{tabular}

More than half of the SIM cohort stated they would start a business just after finishing their masters programme. A third of the cohort stated they would after gaining industry experience. For ES, most seemed to want to work to gain experience before starting a business or those wanting to create a spin-out venture which would need the respondent to be in a secure academic position.

\section{Conclusion}

There were some notable similarities and differences between the students on SIM and ES. Students who chose to do the ES were more broad minded about career options than those doing SIM, who almost all were intent on starting a business and straight after graduating. Of those from ES that wanted to start a business, a number preferred to work in industry first. Also, those from ES wanted to use their entrepreneurial skills to improve society whist those on SIM were motivated by being their own boss and for financial reasons. Both ES and SIM agreed that finance was the biggest barrier to start-up. Overall, it seems that the objectives of encouraging student start-up are achieved by both SIM and ES although the motivations for each group are slightly different. However, an important consideration is that for the SIM a key benefit is that students who do not ultimately start a business have a masters level degree where they have demonstrated a link between their subject area and the commercial world which has been shown to be very attractive to potential employers. It is therefore important that the SIM unit is assessable in a conventional way for a credit bearing unit. For future work, it would be useful to carry out longitudinal studies of those that have participated in these different activities and ascertain whether the students are using these skills if they enter employment. We suggest that the cost of the enterprise 
school per head and the fact that the on-curricular activities provide a recognized qualification in case the business failing means that short intensive off-curricular activities are better suited for researchers with limited time and who are still open minded about career choices. Since the off-curricular activities are funded by grants whilst SIM is funded by more stable students fees and existing infrastructure it is impractical to scale up ES beyond the keenest students each year. This is in agreement with Kneale (2009), however, both activities serve their own purpose and have their own value as they provide the desired interventions for supporting positive attitudes towards enterprise and entrepreneurship.

\section{References}

Artess, J., Hooley, T. \& Mellors-Bourne, R. (2017). Employability: A review of the literature 2012-2016. York: Higher Education Academy.

Bell, R. (2016). Unpacking the link between entrepreneurialism and employability. Education and Training, 58 (1) 2-17. doi.org/10.1108/ET-09-2014-0115.

Crompton, K. (1987). A curriculum for enterprise: Pedagogy or propaganda? School Organization, 7:1, 5-11. doi: 10.1080/0260136870070102.

Fry, H., Ketteridge, S., \& Marshall S. (4 ${ }^{\text {th }}$ ed.). (2015). A handbook for teaching and learning in higher education: Enhancing academic practice. Routledge.

Kneale, P. (2009). Raising student awareness of enterprise skills: accredited and nonaccredited routes, Planet, 21:1, 39-42. doi: 10.11120/plan.2009.00210039.

Martin, B.C., McNally, J.J. \& Kay, M.J. (2013). Examining the formation of human capital in entrepreneurship: A meta-analysis of entrepreneurship education outcomes Journal of Business Venturing, 28(2), 211-224.

Matlay, H. \& Carey, C. (2007). "Entrepreneurship education in the UK: A longitudinal perspective", Journal of Small Business and Enterprise Development, 14(2), 252-263.

Phillips, R. A. (2010). Encouraging a more enterprising researcher: The implementation of an integrated training programme of enterprise for $\mathrm{Ph}$. D. and postdoctoral researchers. Research in Post-Compulsory Education, 15(3), 289-299.

Phillips, R. A. (2017). Measuring entrepreneurial outcomes from a Residential Enterprise School for postgraduate researchers. Journal of Asia Entrepreneurship and Sustainability, 13(2), 62-89.

Phillips, R. A. (2018). A retrospective study on the views of alumni entrepreneurs towards university enterprise education and training IUP. Journal of Knowledge Management, 16(3), 54-71.

Phillips, R.A. (2008). The use of personal journals for assessment of an undergraduate enterprise module. Journal of Asia Entrepreneurship and Sustainability, 4 (4), 77-89.

Sanchez-Romaguera, V. \& Phillips, R.A. (2018). A comparison of a first and final year UG enterprise unit: Lessons from experiential learning and interdisciplinarity. Proceedings of the 4th International Conference on Higher Education Advances 2018, pp.899-907.

The Quality Assurance Agency for Higher Education (2018). Enterprise and Entrepreneurship Education: Guidance for UK Higher Education Providers. 
A comparison of on-curricular and off-curricular activities in enterprise education for PG students

The University of Manchester (2019). MEnt Master of Enterprise - Programme details, Manchester Enterprise Centre. Retrieved from https://www.mbs.ac.uk/ment 